\title{
The evaluation of sustainable development
}

\author{
QuanHui Che ${ }^{1}$ \\ School of North China Electric Power University, Baoding 071000, China \\ 2218461873@qq.com
}

Keywords: sustainability; multi-attribute decision analytic; hierarchy process(AHP)

\begin{abstract}
Recent few decades have witnessed not only the development of the economy and society, but also the increasing damage to the environment. Therefore the definition of "sustained development" has been put forward to do with it, which is called sustainability.

In order to measure the level of sustainability of a country, we have adopted two different kinds of methods to measure it. Model 1 is a model which is based on the theory of multi-attributedecision $^{[1]}$. we select out some dominating factors to respectively reflect aspects of economy, society and environment. Then we adopt analytic hierarchy process ${ }^{[2]}$ (AHP) method get the weight of the factors. Finally, we get the sustainability scores for the five countries we have selected.

In model 2, a indicator of the level of sustainable development is defined. There we use the ratio of a country's social economic benefits and environmental pressure to reflect the sustainable development level of a country. At last we get scores of sustainable development level of these five countries.
\end{abstract}

\section{Introduction}

Sustainable development is a road-map, an action plan, for achieving sustainability in any activity that uses resources and where immediate and intergenerational replication is demanded. As such, sustainable development is the organizing principle for sustaining finite resources necessary to provide for the needs of future generations of life on the planet. It is a process that envisions a desirable future state for human societies in which living conditions and resource-use continue to meet human needs without undermining the "integrity, stability and beauty" of natural biotic systems $^{[3]}$.

The United Nations World Commission on Environment and Development (WCED) in its 1987 report Our Common Future ${ }^{[3]}$ defines sustainable development: "Development that meets the needs of the present without compromising the ability of future generations to meet their own needs." Under the principles of the United Nations Charter the Millennium Declaration ${ }^{[4]}$ identified principles and treaties on sustainable development, including economic development, social development and environmental protection.

\section{Main factors selection for sustainability}

In order to evaluate the sustainability of a country, We will choose some dominating factors from lots of factors covering economy, society and environment to characterize the sustainability of a country. According to the data ${ }^{[5]}$ we select, we choose GNI per capita, per capita gross domestic product, percentage shares in GDP, Annual GDP Growth as economic factors, population growth rate (\%),life expectancy at birth, School enrollment(\%) as social factors, CO2 emissions(metric tons per capita), Improved water source(\% of rural population with access), built-up area green coverage rate(\%) as environmental factors.

\section{Data disposal}

Normalization process aims to determine membership functions. A fuzzy set ${ }^{[6]}$ is defined in 
terms of a membership function which maps the domain of System Indicators (SI) onto the interval $[0,1]$. The membership functions represent the degree that specified value belongs to the set.

Define $a_{i j}$ as the $a_{j}$ value for $i^{\text {th }}$ country and $\max _{j}\left(a_{i j}\right)$ as the maximum $a_{j}$ value for all indicators.

In the following equations, $r_{i j}$ is the proximity of $a_{i j}$ towards the relatively best value of indicators $\mathrm{i}$ among all samples. For value of positive indicators, bigger is better, just as the following equation shown:

$$
r_{i j}=\frac{a_{i j}}{\max _{j}\left(a_{i j}\right)}
$$

Oppositely, as for absolute value of negative indicators, smaller is better:

$$
r_{i j}=\frac{\min _{j}\left(a_{i j}\right)}{a_{i j}}
$$

\section{Obtain the index weight}

When we try to obtain the weight of mainly four aspects as the first class index and the weight of several second class index, subjective judgment is ill-considered. So we choose the Analytic Hierarchy Process ${ }^{[3]}$ (AHP) as the way to conform the weighting coefficient of all the indicators in the evaluation system.

Based on the data we have already collected, we solve the model and obtain the following results:

Judging matrix for economy factors:

$$
\mathrm{A}=\left(\begin{array}{cccc}
1 & 0.5 & 1.5 & 2 / 3 \\
2 & 1 & 5 / 3 & 2 \\
2 / 3 & 0.6 & 1 & 1.5 \\
1 & 0.5 & 2 / 3 & 1
\end{array}\right)
$$

That's the economic index for the five countries.

For this level, satisfying $\mathrm{CI} / \mathrm{RI}=0.01<0.1$

EW1 stands for weight of economy factors:

EW1=[0.2252 0.38080 .21230 .1817$]$

SW stands for weight of society factors,

With the same method SW $=\left[\begin{array}{llll}0.1708 & 0.3461 & 0.2186 & 0.2645\end{array}\right]$

EW2 stands for weight of environment factors :EW2=[0.4 0.20 .4$]$

CW stands for weight of economy, society and environment :CW=[0.4615 0.2308 0.3077]

\section{Model 2 (the SDI Model)}

Seeing that systematic social economic benefits (EB) is proportional to the development goals , while the environmental pressure (EP) is inversely proportional to the sustainable demand ,so we can use the systematic social economic benefits as the numerator in a fraction ,while let the environmental pressure serve as the denominator .In this way, we manage to create a comprehensive evaluation index that proportional to the the sustainable development performance, and we name it sustainable Development Index ${ }^{[7]}$ (SDI. The bigger of the SDI, the higher social economic benefits we get in Unit of environmental pressures and the better sustainability the system gets. The Mathematical expressions of it is :

Among them,

$$
\mathrm{SDI}=\frac{E B}{E P}
$$

SDI: sustainable Development Index EB: systematic social economic benefits

$\mathrm{EP}$ : environmental pressure $\mathrm{EB}=$ Economic output $/$ Economic investment 


\section{Results and analysis}

\section{For Model 1}

After data disposal, each country's scores of economy:ES1 = EW1 . $\mathrm{D} 1=(0.8619,0.3822,0.6127,0.0980,0.101)$

With the same method, each country's scores of society :SS $=\mathrm{SW} \cdot \mathrm{D} 2=$ $(0.8275,0.7217,0.9260,0.4906,0.4776)$

The each country scores of environment: $\mathrm{ES} 2=\mathrm{EW} 2 \cdot \mathrm{D} 3=(0.512,0.4134,0.668,0.7806,0.7072)$

The comprehensive scores of each country :

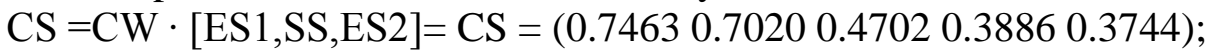

Then we can get the chart:

Table 1 the scores of each country

\begin{tabular}{|l|l|l|l|l|}
\hline & America & Canada & China & Sudan \\
\hline Economic scores & 0.8619 & 0.6127 & 0.3822 & 0.0980 \\
\hline Social scores & 0.8275 & 0.9260 & 0.7217 & 0.4900 \\
\hline Environmental scores & 0.5120 & 0.6680 & 0.4134 & 0.7806 \\
\hline Comprehensive scores & 0.7363 & 0.7780 & 0.4965 & 0.3213 \\
\hline
\end{tabular}

\section{For Model 2 (the SDI Model)}

According to the collected information and data on the issue, we manage to calculate the value.

Table 2 the SDI of each country

\begin{tabular}{lllll} 
& America & Canada & China & Sudan \\
SDI & 0.681285 & 0.791367 & 0.523877 & 0.30867683 \\
\hline
\end{tabular}

\section{The conclusion}

According to the chart above ,we can know that model 1 and model 2 have a similar result, so we can reasonably come to the chart of sustainable development degree evaluation as follows:

Table 3 development degree evaluation

\begin{tabular}{|c|c|c|c|c|c|}
\hline $\begin{array}{c}\text { Sustainable } \\
\text { development } \\
\text { degree }\end{array}$ & $>0.8$ & $0.6 \sim 0.8$ & $0.4 \sim 0.6$ & $0.2 \sim 0.4$ & $<0.2$ \\
\hline Evalution & $\begin{array}{c}\text { High } \\
\text { sustainability }\end{array}$ & $\begin{array}{l}\text { Upper middle } \\
\text { sustainability }\end{array}$ & $\begin{array}{c}\text { middle } \\
\text { sustainability }\end{array}$ & $\begin{array}{l}\text { Lower middle } \\
\text { sustainability }\end{array}$ & $\begin{array}{c}\text { Low } \\
\text { sustainability }\end{array}$ \\
\hline
\end{tabular}

Therefore we can safely come to the conclusion that America and Canada are being in the level of Upper middle sustainability; China being in middle sustainability level while Sudan and Haiti being in Lower middle sustainability level.

\section{References}

[1] Shougui Si, Xi Sun. Mathematical modeling algorithm and application. Beijing: National Defence Industry Press, 2015.2. 358 359.

[2] Qiyuan Jiang, Jingxing Xie . Mathematical model. Beijing: Higher Education Press,2011.

[3] http://www.un-documents.net/our-common-future.pdf

[4] http://en.wikipedia.org/wiki/United_Nations_Millennium_Declaration

[5] National data http : // data. stats. gov. cn / work space /index ?a =q\&type =global \& dbcode =gjnd $\&$ m = gjnd \&dimension=zb\&code=A0101\&region=213\&time=2012,2012

[6] Zhonggeng Han, Mathematical modeling method and its application. Beijing: Higher Education Press,2005.

[7] http://www.cnki.com.cn/Article/CJFDTotal-HJKZ200303029.htm 